\title{
Diagnostic of Andropause: a Problem not yet Solved
}

A ndropause, also known as late-onset hypogonadism (LOH) or hypogonadism in aging males, is due to alterations in the testicular and hypothalamic-pituitary functions (1). A reduction in both the hormone production by the Leydig cells and in the GnRH secretion by the hypothalamus takes place, leading to inadequate secretion of LH by the pituitary (1). Some elders, however, have normal LH levels in the presence of hypogonadism and its increase is not required for the $\mathrm{LOH}$ diagnosis (2). The androgen deficiency in elderly males is normally partial and only a few of them clearly display hormonal levels under the lower limit for young and healthy males, which makes the hypogonadism diagnosis harder in such cases (1).

In this issue of ABE\&M, two articles from Clapauch e cols. $(3,4)$ evaluate the diagnosis of hypogonadism associated to the age in two group of men, with or without osteoporosis. In one of the articles, the total testosterone (TT), calculated free testosterone ( $\mathrm{cFT}$ ), and calculated bioavailable testosterone ( $\mathrm{cBT}$ ) dosages were evaluated (3) and in the other article the relation of those testosterone dosages with three acknowledged questionnaires of the gonadal function evaluation were also analyzed (4).

The decrease of free and total serum testosterone levels is gradual and progresses with age. The total testosterone level remains constant up to the age of 50 to 55 and after that, a progressive decrease takes place $(5,6)$, as confirmed by Clapauch e cols. (3). Free testosterone and albumin-bound testosterone, which represents the bioavailable testosterone, progressively decrease at the ages of 25 to 75 years, due to the continuous increase of SHBG with age $(5,6)$

However, the hypogonadism diagnosis by evaluation of testosterone dosages in blood is not reliable because the procedure may present technical laboratorial difficulties. In the same city there may be clinical laboratories using different methods and normal ranges for testosterone analysis, and that makes each lab responsible to improve its own reference values by themselves (2). In addition to that, weekly variations in the testosterone dosage may occur in elderly men whose testosterone levels vary around the lower limits $(1,2)$, leading to the necessity of at least two dosages in different days, in order to determine hypogonadism with a reliable laboratorial parameter which was also demonstrated by Clapauch e cols. (3).

The signs and symptoms of androgen deficiency are not specific and they can change with age, associated diseases, severity and duration of the androgen deficiency, variation of the androgenic sensitivity and previous testosterone therapy (1). Moreover, the testosterone level threshold under which adverse effects and the onset of androgenic deficiency symptoms are associated is not known (1). For instance, Clapauch e cols. (4) found that total scores equal to or higher than 27 in the Aging Male's Symptoms Scale (AMS) questionnaire were only related to TT levels below $400 \mathrm{ng} / \mathrm{dL}$ and no association was found in $\mathrm{cBT}$ or $\mathrm{cFT}$.

\section{editorial}

\section{Luiz Augusto Casulari \\ lucilia D. Casulari da Motta}

Médico-doutor, orientador do Programa de Pós-Graduação em Ciências da Saúde da Universidade de Brasília (LAC)

Professora-associada da Área de Obstetrícia e Ginecologia da Universidade de Brasília (LDCM), Brasiília, DF, Brasil 
Clapauch e cols. (4) also evaluated the advantage of three questionnaires as the screening tool for $\mathrm{LOH}$ diagnosis: Androgen Deficiency of the Aging Male, AMS, and International Index of Erectile Function (IIEF-5) (for references, please see 4). However, no important correlation between the total testosterone (TT), calculated free testosterone (cFT) and calculated bioavailable testosterone (cBT) with three questionnaires was found.

Testosterone is a pro-hormone which originates two other hormones that are active in the male metabolism: estradiol $\left(\mathrm{E}_{2}\right)$ and 5-alpha-dihydrotestosterone $(\mathrm{DHT})(7,8)$. It is thus not surprising that no form of testosterone evaluation was related to the questionnaires evaluated by Clapauch e cols. (4), accordingly to all other studies mentioned in the article, which also evaluated circulating testosterone forms, but not its active metabolites (4). Free and bioavailable $\mathrm{E}_{2}$ levels can decline due to the increase of SHBG (7) and this may jeopardize its beneficial effect on bone, brain, lipids, and cardiovascular system (7). Nevertheless, a correlation between the $\mathrm{E}_{2}$ level and AMS scale was not observed (9). Testosterone is converted by 5 -alpha-reductases into DHT which has an important action in sexual activity, sexual characters and brain (8). The use of transdermal DHT significantly improved sexual function evaluated by IIEF-5 (8), a typical action of the DHT not correlated with the testosterone levels of the study presented by Clapauch e cols. (4).

The syndrome related to the male aging process, evaluated by the questionnaires, could also be due to factors other than the testosterone level decrease, such as the age-related deficit of GH and IGF-1, central and peripheral nervous system alterations, inactivity and immobility $(1,2)$. On the other hand, the age-related declination of testosterone levels is almost not seen in healthy males, which are those who do not have any chronic disease or who have a healthy lifestyle (5) and a significant number of males remain eugonadic even at advanced ages (6).

In conclusion, the use of questionnaires used in the study made by Clapauch e cols. (4) for andropause diagnosis is not recommended ( 1 ); the diagnosis for androgen deficiency should only be made in males with consistent testosterone-deficiency-related symptoms and signs and with an unequivocal decrease of testosterone levels $(1,2)$; in addition, hormonal dosage as the screening tool for androgen deficiency is not recommended in the general population (1).

\section{REFERENCES}

1. Bashin S, Cunningham GR, Hayes FJ, Matsumoto AM, Snyder PJ, Swerdloff RS, Montori VM. Testosterone therapy in adult men with androgen deficiency syndromes: an Endocrine Society Clinical Practice guideline. J Clin Endocrinol Metab. 2006;91(6):1995-2010.

2. Martits AM, Costa EMF. Hipogonadismo masculino tardio ou andropausa. Rev Assoc Med Brasil. 2004;50(4):349-62.

3. Clapauch R, Carmo A, Marinheiro L, Buksman S, Pessoa I. Laboratory diagnosis of late-onset male hypogonadism (Andropause). Arq Bras Endocrinol Metab. 2008;52;1430-8.

4. Clapauch R, Braga DJC, Marinheiro LP, Salo Buksman S, Schrank Y. Risk of late-onset hypogonadism (andropause) in Brazilian men over 50 years of age with osteoporosis: usefulness of screening questionnaires. Arq Bras Endocrinol Metab. 2008;52;1439-47.

5. Muller M, den Tonkelaar I, Thijssen JH, Grobbee DE, van der Schouw YT. Endogenous sex hormones in men aged 40-80 years. Eur J Endocrinol. 2003;149(6):583-9.

6. Feldman HA, Longcope C, Derby CA, Johannes CB, Araujo AB, Coviello $A D$, et al. Age trends in the level of serum testosterone and other hormones in middle-aged men: longitudinal results from the Massachusetts male aging study. J Clin Endocrinol Metab. 2002;87(2):589-98.

7. Gooren LJ, Toorians AW. Significance of oestrogens in male (patho)physiology. Ann Endocrinol (Paris). 2003;64(2):126-35.

8. Kunelius P, Lukkarinen O, Hannuksela ML, Itkonen O, Tapanainen JS. The effects of transdermal dihydrotestosterone in the aging male: a prospective, randomized, double blind study. $\mathrm{J}$ Clin Endocrinol Metab. 2002;87(4):1467-72.

9. Miwa $Y$, Kaneda $T$, Yokoyama O. Correlation between the Aging Males' Symptoms Scale and sex steroids, gonadotrophins, dehydroepiandrosterone sulfate, and growth hormone levels in ambulatory men. J Sex Med. 2006;3(4):723-6.

\section{Correspondence to:}

Luiz Augusto Casulari

SCN quadra 1 bloco F Ed. America Office Tower sala 1105

7071 1-905 Brasilia DF

E-mail: lacasulari\&unb.br 